\title{
Levels of Workforce Structure in Ahirwal Region of Haryana: A Spatio-Temporal Analysis
}

\author{
Ankita Yadav \\ Department of Geography, Kurukshetra University, Kurukshetra, Haryana, India \\ E-Mail: ankitayadav6943@gmail.com
}

\begin{abstract}
The present study discusses the levels of workforce structure in Ahirwal region, which is a socio-cultural region laying in southern Haryana. For the study of workforce structure of this region, a composite index has been constructed with the help of seven indicators. The data related to workforce indicators have been collected from Census of India, Office of the Registrar General of India, for the period 1991, 2001 and 2011. The analysis brings out that the level of workforce development in Ahirwal region was not different from that of rest of state in 1991. But this region surged ahead of the rest of state average in 2001. By 2011 Ahirwal region was far ahead of the rest of state in terms of workforce development. However, there has been a significant interdistrict difference in this regard in Ahirwal region. Gurugram district has been quite ahead of Rewari and Mahendragarh districts in terms of workforce development.

Keywords: WorkParticipation Rate, Workforce Structure, Interdistrict Variations, Ahirwal Region
\end{abstract}

\section{INTRODUCTION}

Changes in the size, composition and distribution of population are closely associated with the demographic structure of workforce. The workforcestructure variesaccording to the stages of economic development, across cultures, age groups, and between sexes (Bhagat and Das, 2008). Economic reforms have accelerated the growth and expanded the employment opportunities in the country (Motkuri and Naik, 2016;Himanshu, 2011).Growth has been particularly rapid since the post reform period of the 1990s. This high growth has contributed to a sustained increase in per capita income and a decline in absolute poverty, as well as modest improvement in standards of living. It has also brought important changes in employment conditions in the country (India Labour and Employment Report, 2014). Furthermore, it has emphasized on promoting labourintensive and high employment elasticity sectors to achieve the quantitative employment growth target (Government of India, 2011). National Sample Survey Office's (NSSO) estimations with respect to its employment and unemployment survey brought out a virtual stagnation in the employment growth, indicating jobless growth in the Indian economy (Abraham, 2009;Ghosh, 2013; Mehrotra et al., 2013).

Further, work participation is an important indicator for understanding the socio-economic development of various segments of the population of a country. Percentage of workforce to the total population reflects the economically active working population (15-60 age group). In India, Haryana is one of the most economically developed state. A significant economic development has been observed in the state during post-liberalization period. Therefore,the present study seeks to understand the impact of economic liberalization on pattern of workforce structure in Ahirwal region viz-a-viz rest of Haryana during last two decades. It also assesses the growing interdistrict disparity in the level of workforce structure in the region.

\section{OBJECTIVES OF THE STUDY}

In the light of above review, this study seeks to achieve the following two major objectives

1. To study the patterns of workforce structure in Ahirwal region viz-a-viz the rest of Haryana during 1991, 2001 and 2011.

2. To examine the interdistrict disparity in the level of workforce structure within the region during 1991, 2001 and 2011.

\section{STUDY AREA}

The present study pertains to Ahirwal region which is a socio-cultural region of Haryana lying in the cradle of Aravalli ranges in southern part of the state. The boundary of this region does not actually coincides the boundary of administrative units. The districts of Gurugram, Rewari and Mahendragarh, however, constitute bulk of its territory. Hence, for the purpose of present study these three districts together constitute Ahirwal region in the state (Fig. 1). Ahirwal region extends between latitudes $27^{\circ} 79^{\prime}$ to $28^{\circ} 54^{\prime}$ $\mathrm{N}$ and longitudes $75^{\circ} 89^{\prime}$ and $77^{\circ} 24^{\prime} \mathrm{E}$. It is bordered by Bhiwani and Jhajjar districts in the north, Delhi, Faridabad, Palwal and Mewat districts in the east and Rajasthan state in the west and south. It covers a geographical area of about $4751 \mathrm{~km}^{2}$, forming about 10.74 percent of the total geographical area of the state and accounting for 13.16 percent of the total population in 2011.

\section{DATA AND METHODOLOGY}

The present study is based on secondary data. The data related to various aspects of workforce structure parameters have been collected from Census of India, Office of the Registrar General of India. The data used in the study pertains to the year 1991, 2001 and 2011. Following seven 
indicators of workforce structure have been selected for the present study.

1. Total work participation rate

2. Rural work participation rate

3. Urban work participation rate

4. Male work participation rate

5. Female work participation rate

6. Proportion of non-agricultural workers to total workers

7. Proportion of female non-agricultural workers to total female workers

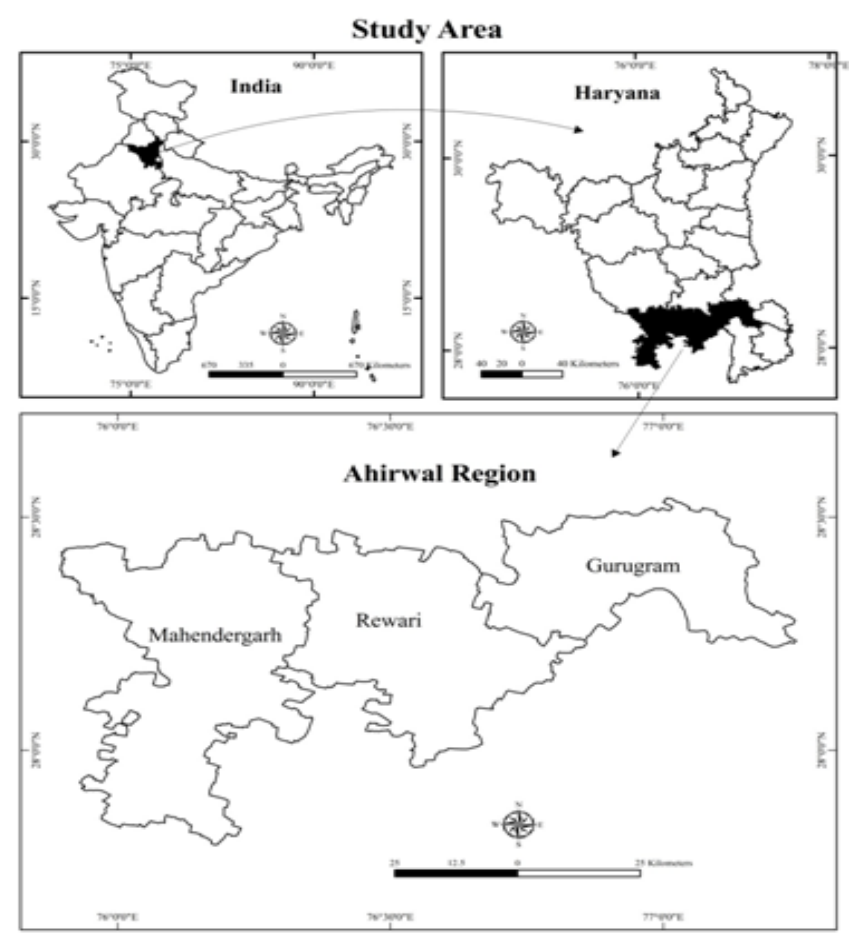

Fig.1 Location map of Ahirwal region

Analysis of individual indicator of workforce structure does not provide an integrated and easily comprehensible picture of the social development. Therefore, the composite index of workforce structure has been constructed by dividing the observations of the indicators by the state average value (Kundu, 1992). Division of the indicator's values for rest of Haryana, Ahirwal region and the districts of the region by the state average has made the series free of the bias of scale without affecting the relative position of different geographical units. The scale free values of different indicators so obtained have been summed up and subsequently divided by the number of indicators to get the composite index of workforce structure.

\section{RESULTS AND DISCUSSION}

\section{A. Pattern of Workforce Structure Indicators}

\section{Total Work Participation Rate}

Figure 2 shows the percentage of work participation was 30 percent in 1991 which increased to 39.62 percent in 2001 but slightly decline in 2011 (34.96 percent) in the state. In the case of Ahirwal region it had increased to 30.68 percent to 40.61 percent between 1991 and 2001 but decline in 2011 which is 36.59 percent. It is evident that Ahirwal region and the state have almost similar pattern in work participation rate. Ahirwal region had recorded slightly high work participation rate than the state average. In 1991, Gurugram district (32.06 percent) had recorded highest work participation rate and lowest in Rewari district (27.79 percent) (Fig. 3). However, Rewari district had highest work participation rate which varies from 43.59 percent to 37.51 percent during 2001 and 2011. The lowest work participation rate found in Gurugram district varies from 37.92 percent to 35.97 percent during same time period.

\section{Rural and Urban Work Participation Rate}

Figure 2 depicts the rural work participation was 31.87 percent in 1991 which increased to 42.93 percent in 2001 and slightly declined to 36.36 percent in 2011 in the state. In 1991, rural work participation rate in Ahirwal region was 31.29 percent which had increased from 31.86 percent to 42.74 percent during 2001 and 2011. The rural work participation has continuously increased in Ahirwal region as well as the state average. Also similar pattern has been observed in the state average and Ahirwal region. The urban work participation rate in Ahirwal region was 27.68 percent in 1991 which declined to 31.21 percent in 2001 and increased to 34.51 percent during 2011. Similarly, it has also increased in the state which varies from 28.32 percent to 32.95 percent during 1991 to 2011. Urban work participation rate is higher in Ahirwal region than the state average during 2011.

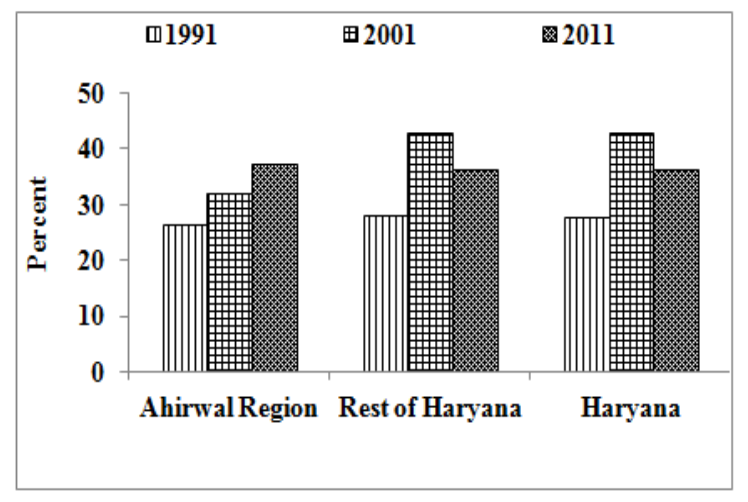

(a)

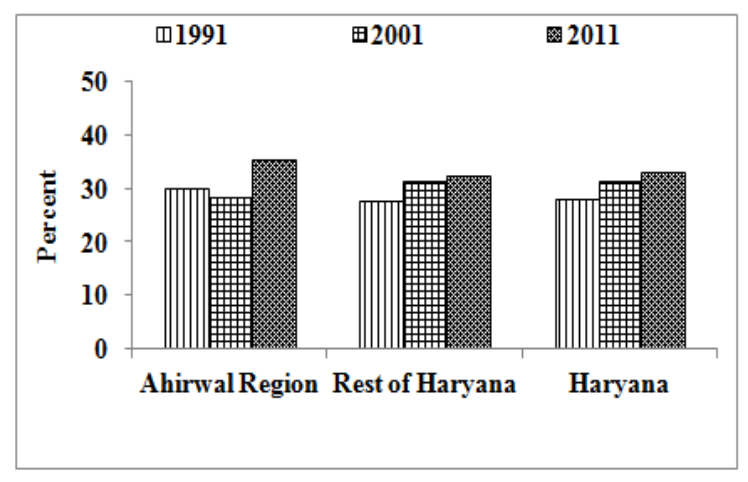

(b) 


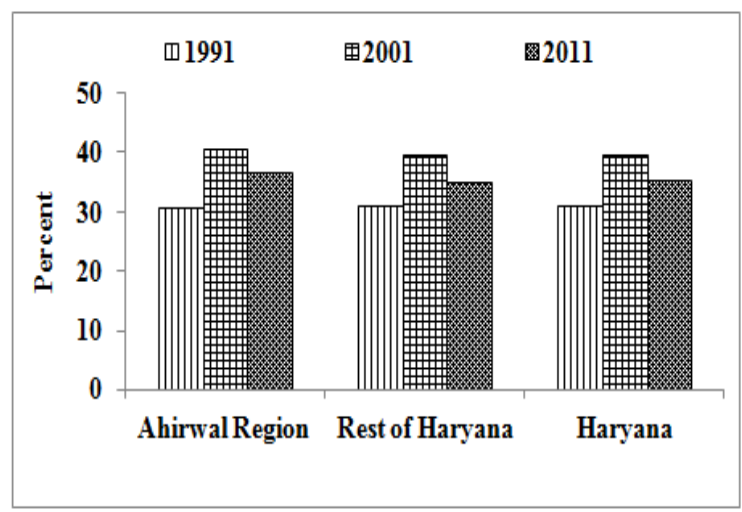

(c)

Fig. 2 Percentage of (a) rural, (b) urban and (c) total work participation rate In Ahirwal region, rest of Haryana and Haryana from 1991 to 2011

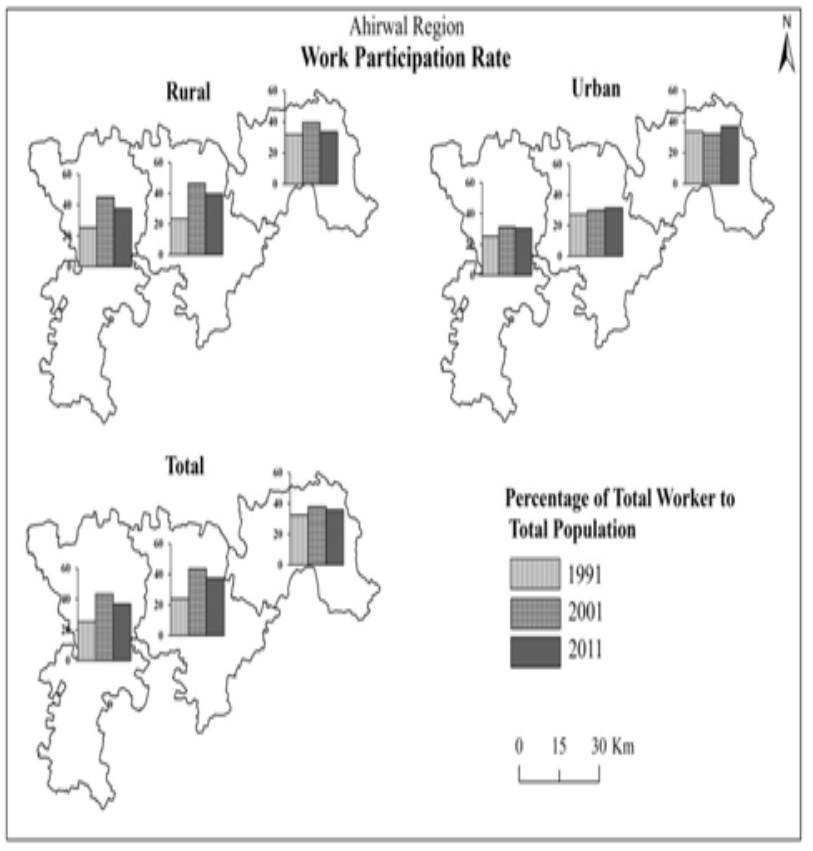

Fig. 3 Percentage of rural, urban and total work participation rate in the districts of Ahirwal region from 1991 to 2011

From the above discussion, we concluded that the work participation rate of rural is more than urban work participation rate in the state, rest of Haryana and the study region during the entire period. The work participation rate in both urban and rural areas is higher in Ahirwal region than the state average in 2011. Figure 3 exhibits there are interdistrict variation in rural urban work participation rate within Ahirwal region. Rewari district had highest rural work participation rate which varies from 46.50 percent to 39.64 percent in 2001 and 2011. However, the lowest rural work participation rate found in Gurugram district varied from 39.58 percent to 33.56 percent during same time period but conversely pattern has been observed in urban work participation rate.

\section{Male and Female Work Participation Rate}

The male work participation rate was 45.08 percent in 1991 which increased to 48.35 percent in 2001 and further improved to 50.67 percent during 2011 in the study region (Fig. 4). Similarly, it had increased from 49.10 percent to 50.74 percent between 1991 to 2001 and slightly decline to 50.40 percent during 2011 in the rest of Haryana. The male work participation rate has gradually increased from 1991 to 2011 in the study region as well as the rest of Haryana. But the rest of Haryana had high male work participation rate than the study region during 1991 to 2001 and almost similar figure in 2011.

Fig.5 also depicts the female work participation rate had increased from 10.76 to 27.22 percent during 1991 and 2001 which decrease to 17.79 percent in 2011 in the state. It had drastic increased from 14.60 to 32.54 percent during same time period whereas it also decreased to 20.54 percent in 2011 in the study region. Till 2001, the Female work participation rate has continuously increased in the state, rest of Haryana as well as Ahirwal region whereas it has recorded decline in 2011. Female work participation is high in Ahirwal region as compared to the state and rest of Haryana during last decade.

The male work participation rate has gradually increased in all the districts of Ahirwal region. However, Gurugram district had recorded highest male work participation during the study period whereas lowest found in Mahendragarh district except 1991 (Fig. 5).

Till 2001, a rapid increase in the female work participation had been observed in all the district of Haryana but in 2011 all the districts of Ahirwal region showed decline in the female work participation rate. Mahendragarh district had registered highest female work participation rate which varies from 15.90 percent to 24.26 percent between 1991 to 2011. However, the lowest female work participation rate found in Gurugram district except 1991 which varies from 27.72 to 16.09 percent between 2001 and 2011. It can be seen from the figure that there has been a greater improvement in female work participation rate as compared to male work participation rate in all districts of the region. Over the decades, the gender gap in the work participation rate has narrowed down considerably in all the districts of Ahirwal region

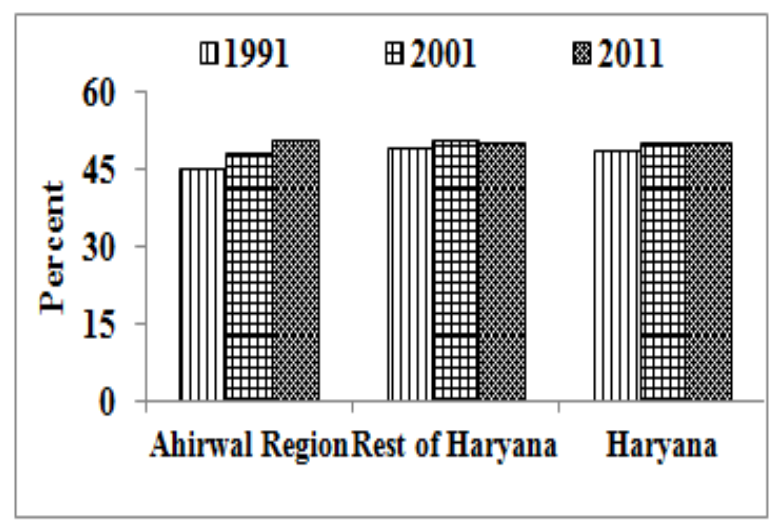

(a) 


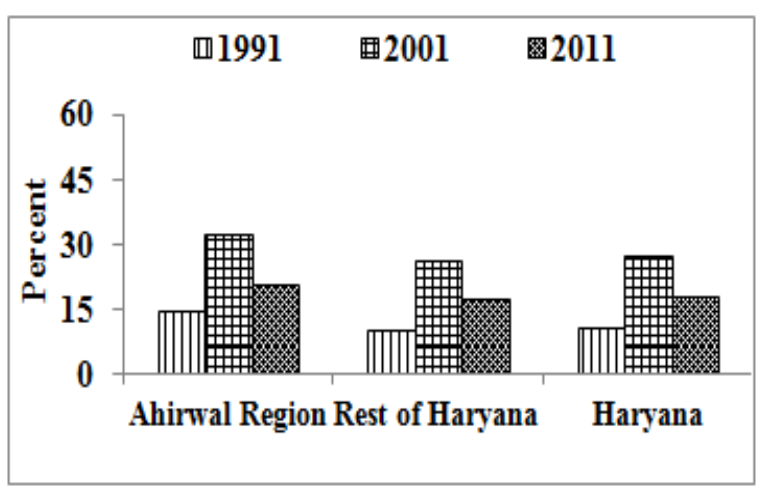

(b)

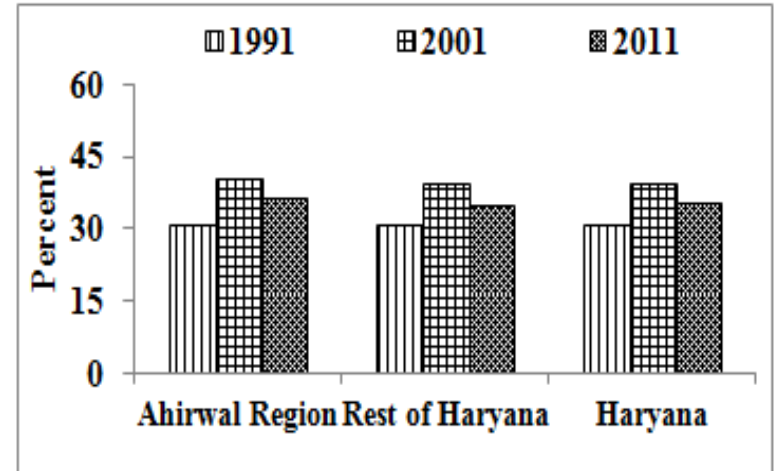

(c)

Fig. 4 Gender wise variation in percentage of (a) rural, (b) urban and (c) total work participation ratein Ahirwal region, rest of Haryana and Haryana from 1991 to 2011

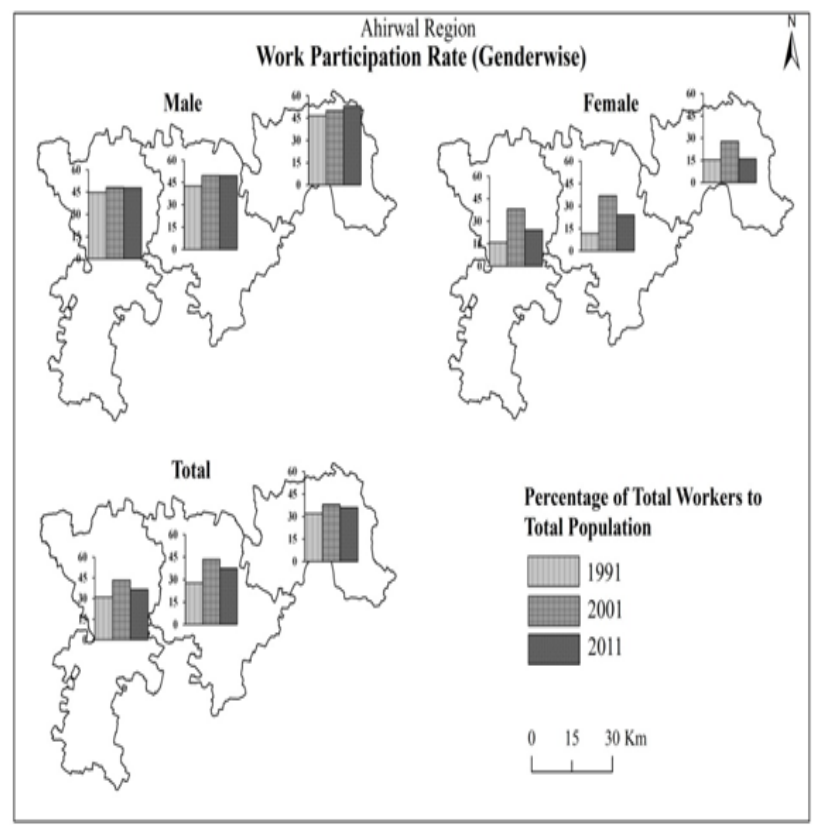

Fig. 5 Gender wise variation in percentage of male, female and total work participation ratein the districts of Ahirwal region from 1991 to 2011

\section{Non-Agricultural Workers}

The proportion of non-agricultural workers is one of the important indicators of economic development for any region. The region where higher proportion of non- agricultural workers is considered to be economically and socially developed and vice-versa. The proportion of nonagricultural worker had increased considerably over proportion of non-agriculture worker has continuously increased in the state, rest of Haryana as well as Ahirwal region. However, the proportion of non-agricultural workers is high in Ahirwal region than the state averageduring last two decades (Fig. 6). Inter-district variation in the proportion of non-agricultural workers can also be seen from Figure 7. The proportion of non-agricultural workers had continuously increased in all the districts of Ahirwal region. But, Gurugram district had recorded highest proportion of non-agricultural workers which varies from 53.98 to 84.74 percent between 1991 to 2011 . The lowest proportion of non-agricultural workers found in Mahendragarh district varies from 33.09 to 44.63 percent between 1991 to 2011. The percentage of urban nonagriculture workers have high compared to rural nonagriculture workers in the study area as well as overall Haryana and rest of Haryana. However, the percentage of rural and urban non-agriculture workers have high in the Ahirwal region compared to the rest of Haryana.

\section{Female Non-Agricultural Workers}

Fig.8 reveals the proportion of female non-agriculture workers was 16.80 percent and 11.90 percent in Ahirwal region, respectively. It was quite low in Ahirwal region than the state. It had rapidly increased in the state which varies from 35.23 to 44.14 percent between 2001 and 2011 . Similarly it has also exponentially increased in Ahirwal region which varies from 32.87 to 53.51 percent during same time period.

The female non-agricultural workers had continuously increased in the state as well as Ahirwal region. But it had high in Ahirwal region than the state average during last one decade. It had continuously increased in all the districts of Ahirwal region (Fig. 9). Gurugram district had registered highest proportion of non-agricultural workers varies from 24.28 to 84.74 percent between 1991 to 2011. During similar time period, the lowest proportion of nonagricultural workers found in Mahendragarh district varies from 5.46 to 26.54 percent.

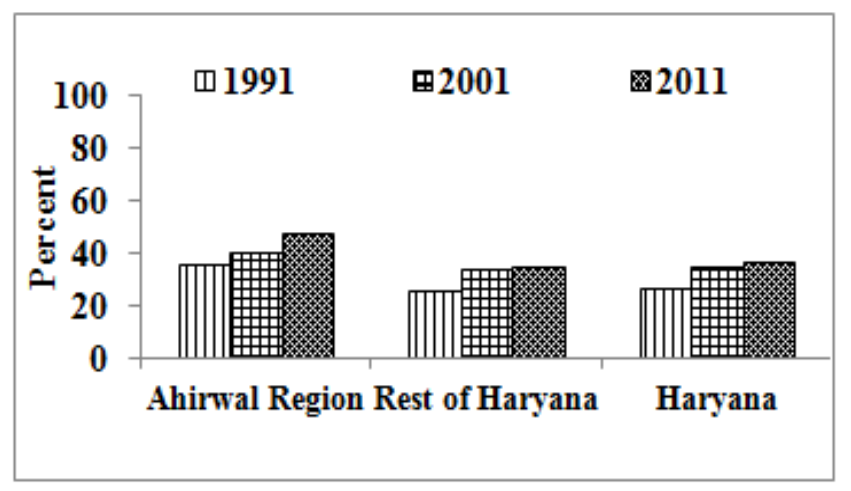

(a) 


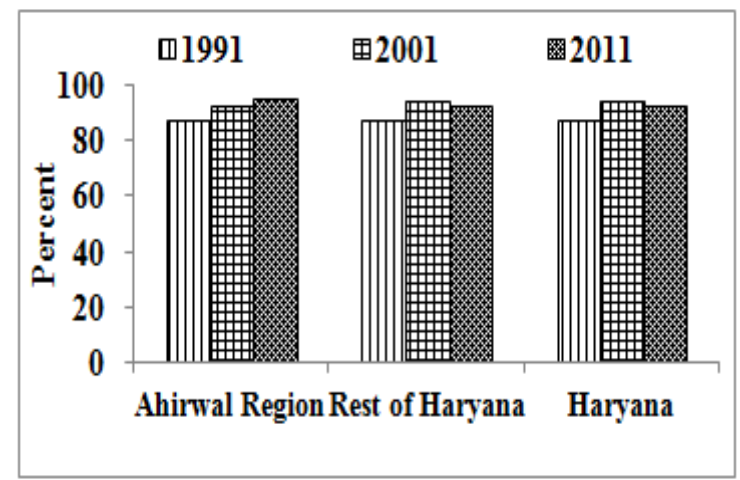

(b)

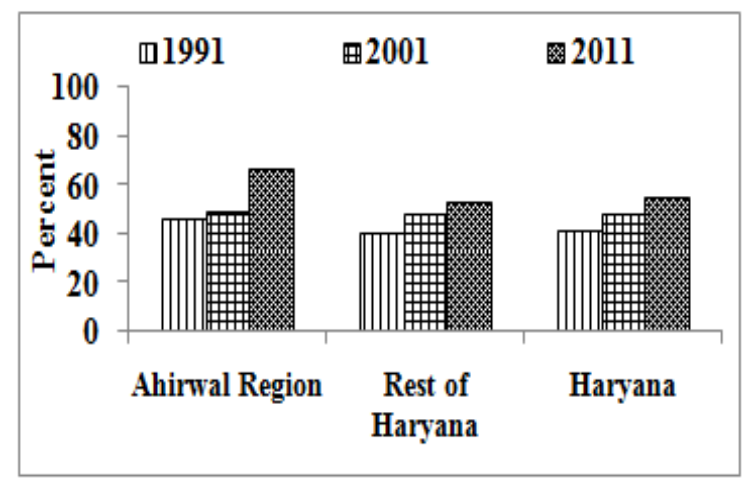

(c)

Fig. 6 Percentage of (a) rural, (b) urban and (c) total non-agricultural workersin Ahirwal region, rest of Haryana and Haryana from 1991 to 2011

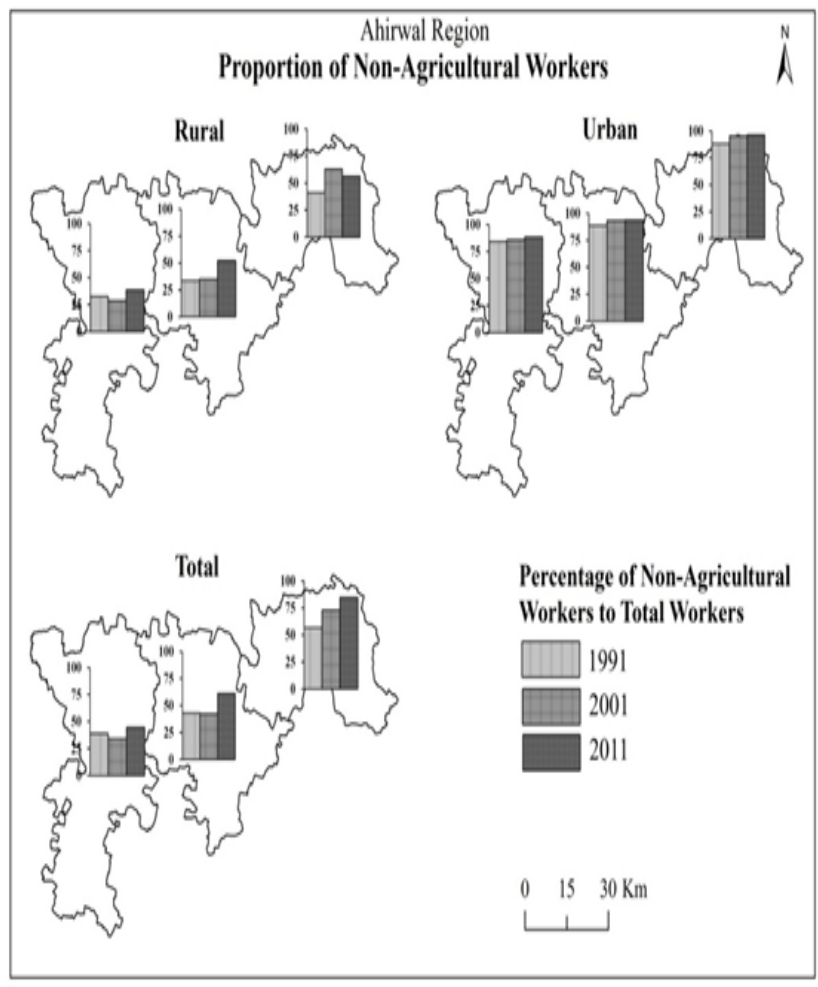

Fig.7P ercentage of rural, urban and total non-agricultural Workers in the districts of Ahirwal region from 1991 to 2011

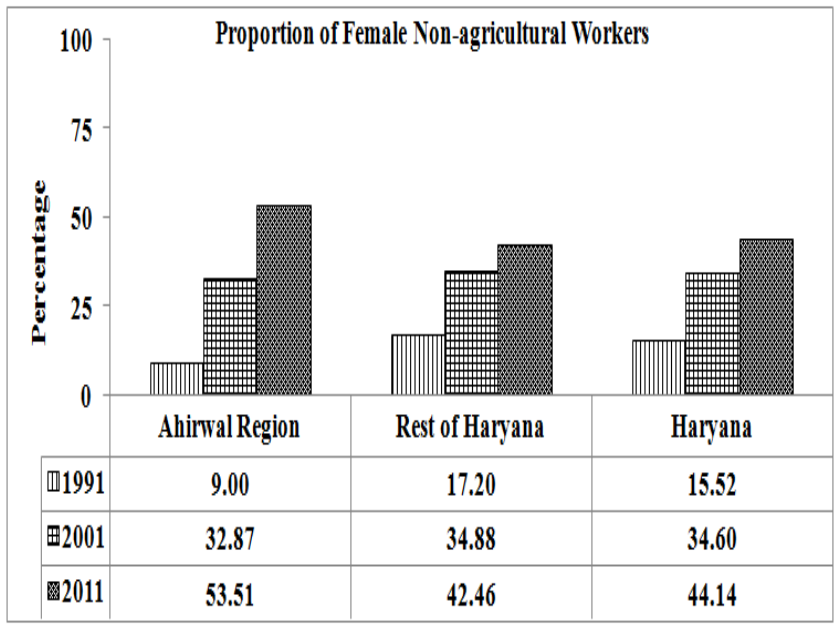

Fig. 8 Percentage of female non-agricultural workers in Ahirwal region, rest of Haryana and Haryana from 1991 to 2011

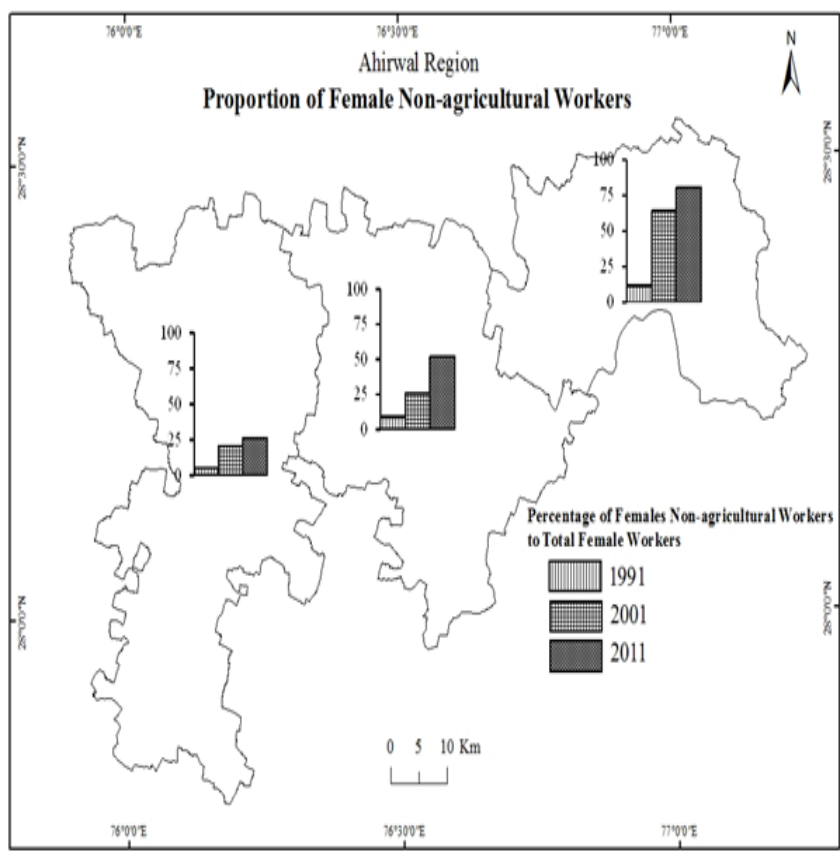

Fig. 9 Percentage of female non-agricultural workersin the districts of Ahirwal region from 1991 to 2011

\section{B. Levels of Workforce Structure}

It has been observed from Table I that the value of the scores of workforce structure varied from 1.00 to 1.04 between 1991 and 2001 which increased to 1.13 in 2011 in the study region. The value of the score in the rest of Haryana was 0.99 in 1991 and figure unchanged in 2001 and slightly continuously to 0.98 in 2011. It is evident that the highest value of the score found in Ahirwal region as compared the rest of Haryana in the case of workforce structure.

Table I also depicted the district wise value of score in the study region in respect to workforce structure. Gurugram district has recorded the highest value of the score whereas Mahendragarh district has registered the lowest value of score during last two decades. 
TABLE I COMPOSITE INDEX OF WORKFORCE DEVELOPMENT

\begin{tabular}{|l|c|c|c|}
\hline Districts & $\mathbf{1 9 9 1}$ & $\mathbf{2 0 0 1}$ & $\mathbf{2 0 1 1}$ \\
\hline Gurugram & 1.09 & 1.33 & 1.32 \\
\hline Rewari & 0.88 & 1.02 & 1.18 \\
\hline Mahendragarh & 0.89 & 0.95 & 0.95 \\
\hline Ahirwal Region & 0.97 & 1.05 & 1.16 \\
\hline Rest of Haryana & 1.01 & 0.99 & 0.97 \\
\hline \multicolumn{4}{|c|}{ Source: Computed by Researcher }
\end{tabular}

\section{CONCLUSION}

This study presents a detailed analysis of levels of workforce structure in Ahirwal region viz-a-viz rest of Haryana. The analysis reveals that there is not much difference in work participation rate between Ahirwal region and rest of Haryana. But the pace of increase in work participation rate is higher in Ahirwal region. Rewari district had highest (38 percent) work participation rate and it was found to be lowest (36 percent) in Gurugram district in 2011.Both rural and urban work participation rates were higher in Ahirwal region as compared to the rest of Haryana in 2011. Overall, rural work participation rate has declined in Ahirwal region between 2001 and 2011. However, urban work participation rate in the region has increased significantly. Between 1991 and 2001, a rapid increase in the female work participation was observed in all the districts of region. But in 2011, all the districts of Ahirwal region had showed decline in the female work participation. Incidentally least urbanized Mahendragarh district registered highest female work participation rate which increased from 15.90 percent to 24.26 percent over the decade 1991 to 2011. However, the lowest female work participation rate was found in Gurugram district.

The proportion of non-agricultural workers has increased in the state of Haryana including Ahirwal region over last two decades. However, it has been higher in Ahirwal region in comparison to rest of state during last two decades. In 2011 Gurugram district had recorded highest proportion of nonagricultural workers (85 percent) and lowest proportion was found in Mahendragarh district (45 percent).The proportion of female non-agricultural workers has also increased impressively in the state as well as Ahirwal region. But in 2011 it was quite high in Ahirwal region (54 percent) compared to the state average. It has continuously increased in all the districts of Ahirwal region over last two decades. But Gurugram district had registered highest proportion of non-agricultural female workers (80 percent) and lowest was found in Mahendragarh district (27 percent).

The index value of workforce development in Ahirwal region has consistently increased over the period 1991 to 2011. The level of workforce development in Ahirwal region was not different from that of rest of state in 1991. But this region surged ahead of the state average in 2001. By 2011 Ahirwal region was far ahead of the rest of state in terms of workforce development. However, there has been a significant interdistrict difference in this regard in Ahirwal region. Gurugram district has been quite ahead of Rewari and Mahendragarh districts in terms of workforce development. Rewari district has an improvement in workforce development but Mahendragarh district continues to be least developed district in the region.

\section{REFERENCES}

[1] Government of India. (2011). Second annual report to people on employment. Ministry of Labour and Employment, Government of India.

[2] Ghosh, J. (2013). The strange case of the jobs that did not appear:Structural change, employment and social patterns in India. Presidential Address at the 55th Annual Conference, The Indian Society of Labour Economics, 16-18 December, CESP, JNU, New Delhi.

[3] Mehrotra, S., Gandhi, A., Saha, P. and Sahoo, B. (2013). Turn around in India's employment story: silver lining amidst joblessness and informalization? Economic \& Political Weekly, 48(35), 87-96.

[4] Bhagat, R.B. and Das, K.C. (2008). Levels, trends and structure of workplace in India: census based study 1981-2001. International Institute for Population Sciences, Mumbai, India.

[5] Motkuri, V. and Naik, S. V. (2016). Growth and structure of workforce in India: an analysis of census data. Indian Economic Journal, 64(1\&2), 57-70.

[6] Abraham, V. (2009). Employment growth in rural India: distress driven? Economic \& Political Weekly, 44(16),97-104.

[7] Himanshu,(2011). Employment trends in India: a reexamination. Economic \& Political Weekly, 46(37), 43-59.

[8] Government of India. (2014). India labour and employment report 2014: workers in the era of globalization, Academic Foundation, New Delhi \& Institute for Human Development, New Delhi. 